\title{
Regulation of mutagenesis by exogenous biological factors in the eukaryotic cell systems
}

\author{
L. L. Lukash \\ Institute of Molecular Biology and Genetics, NAS of Ukraine \\ 150, Akademika Zabolotnogo Str., Kyiv, Ukraine, 03680 \\ lukash@imbg.org.ua
}

\begin{abstract}
The representations of the mutations and the nature of spontaneous mutation process and mutagenesis induced by exogenous oncoviruses, DNAs and proteins-mitogens are analysed. Exogenous biological factors induce DNA damages in regulatory-informational way, acting on the cellular systems for maintenance of genetical stability. Molecular mechanisms are the same as at spontaneous mutagenesis but they are realized with the participation of alien genetical material. Among biological mutagens, the oncoviruses and mobile genetic elements (MGEs) are distinguished as the strongest destabilizing factors which direct tumor transformation of somatic mammalian cells. Genetical reprogramming or changing the programs of gene expression at the differentiation of stem and progenitor cells under growth factors and citokines is probably followed by mutations and recombinations as well.
\end{abstract}

Keywords: mutagenesis, mutation, eukaryotic cell, oncovirus, MGE, protein-mitogen.

Introduction. Problems of mutagenesis move to the forefront of science and society development in connection with anthropogenic pollution of the environment and accumulation of mutations in genomes of human and other organisms. According to one of the forecasts there are increasing frequency of hereditary and somatic diseases, reduction in longevity and other adverse effects. According to other forecasts there is a process of accelerated evolution which leads to the emergence of new forms of life. The achievements of modern science will promote new technologies which might be applied for reorganization of own genome into the hands of the mankind.

Each time after discovering mutagenic action of physical, chemical or biological mutagens there was observed long «lag period» when no proper attention was paid to these investigations. However, starting from the middle of the 1970s there was observed avalanche-like accumulation of the number of works devoted to the genetic consequences of mutagens action in the human

(C) Institute of Molecular Biology and Genetics, NAS of Ukraine, 2013 habitat, especially «supermutagens» $[1,2]$. It resulted in forming certain ideas about mutations and mechanisms of realization of the mutagen impacts on cell systems, prospects and directions of further researches.

Some actual questions of mutagenesis, both spontaneous and induced by various factors, were discussed at a thematic seminar «Fundamental problems of mutagenesis» in the IMBG NASU as well as on the pages of special issue of the journal «Biopolym. Cell» in 2007. New data, allowing the development of ideas about spontaneous and induced mutagenesis appeared since that time.

This review is devoted to some questions of spontaneous mutagenic process and to the detailed consideration of features and mechanisms of mutagenesis, induced by biogenic factors, in the populations of the eukaryotic cells because the literature data on induced mutagesis are insufficient and inexact. The researches on viruses, viral vaccines and exogenous DNAs gave the basic material for development of comprehension on biological mutagenesis in eukaryotic cell systems in vi$v o$ and in vitro [3-7]. Hesin [8] for the first time genera- 
lized the data on the existence of cell mechanisms, which control the mutational variability and can cause sharp destabilization of a genome or «mutational explosions» under stressful conditions, and thus marked a special role of oncoviruses and mobile genetic elements (MGEs) in this phenomenon.

We use the term «biological mutagenesis» in a broad sense, meaning various genetical changes caused by biogenic factors while some authors under this term imply insertion-deletion mutagenesis only [9].

Mutations and spontaneous mutagenic process. Ability to change the genetic material or to mutate is a universal property of living forms from viruses and microorganisms to the highest plants, animals and human beings. The term «mutation» was offered by Gugo de Frieze at the beginning of the last century in his classical work «Mutation theory», the substantive provisions of which still have not lost their value. Since that time, mutations imply discrete, stable changes of a hereditary material manifested in the phenotype. The process of mutations emergence is named mutagenic or mutagenesis although the latter term is more often used in regard to the mutations induced by mutagens [2]. At the present stage of genetics development the most generally accepted is a short definition of mutations - «mutational variability is inherited changes of genetic material» $[10,11]$ although the essence of the changes happening at submolecular levels of the DNA organization thus is not disclosed.

Arising genetic changes can affect only sequences of nucleotides in DNA (gene or point mutations), to result in reorganizations within chromosomes (chromosomal aberrations), and to induce increasing or reducing number of separate chromosomes (aneuploidy) or the whole sets of chromosomes (genomic mutations) [1, 2, $10,11]$. Detection of «strange» properties of the mutations induced by exogenous DNAs and viruses (locus specificity, instability, domination of minideletions), maybe, for the first time seriously affected the initial ideas about stability of the acquired genetic changes [3, $12,13]$.

In the last decades it was created the concept about the macromutations manifested by large structural reorganizations of genomes in the course of their evolution, such as: a) insertions and deletions of nucleotide sequences during integration of MGEs, oncoviruses, exoge- nous DNAs; b) reorganizations which change the number of chromosomal sets, appearance and elimination of separate chromosomes, 3) diminution of chromatin (elimination of genetic material when forming somatic cells from the germinal cell line of some organisms). In the majority of organisms the isolation of genetic material is reached by means of supercompact piling of chromosomes $[10,14]$. A new point in the understanding of the nature of mutations is a consideration that the epigenetic changes caused by DNA methylation are the manifestation of «epigenetic mutagenesis»; which followed by induction of DNA damages $[15,16]$.

Macromutations are probably the most powerful factors of genome destabilization and at the same time a source of its accelerated evolution. As an example can be an extraordinary high rate of evolution of an Asian forest mouse, the karyotype of which consists of 23 pairs of autosomes, a pair of sexual and 9 additional Bchromosomes which serve as genetic material for reorganizations [17]. The DNA excess and nucleotide sequences of various degree of repeatability in heterochromatin regions of chromosomes of different species play a special role in these processes $[9,10,14-18]$.

Spontaneous mutagenesis, $i$. e. the emergence of mutations at the lack of intended treatment by mutagens, represents a final result of total influence of various factors on the processes of replication, reparation, recombination, modifications and restriction in the course of normal cellular metabolism $[1,2,10]$. It is considered that endogenous factors comparing to exogenous ones make bigger input into spontaneous mutagenesis, and DNA replication is one of the chief «suppliers» of mistakes $[1,2,10]$.

Mutations are the source of genetic variety as a necessary condition for the development and adaptation of organisms; probably therefore the relatively permanent rate of a spontaneous mutagenesis, characteristic of given species or cell types was evolutionarily fixed $[1,2,19,20]$. As a rule, the frequency of spontaneous mutations in the highest eukaryotes is characterized by low value of $10^{-5}-10^{-8}$ per a gene per one generation. And the parameter reverse to the frequency of spontaneous mutations reflects the level of genetic stability of the biological systems and is hereditary fixed sign [21]. However, fluctuations of the frequency of spontaneous mutations for various cellular populations of an orga- 
nism can differ by thousands times $[1,2]$. There is an amazing example of self-regulated mutagenesis of human organism: during all life high mutational rate is maintained in the populations of the antibody producing cells but such genetic instability is strictly limited to the certain hypervariable sites of the corresponding immunoglobulin genes [22].

Apparently, a certain level of genetic stability and variability of different DNA locuses is encoded in the structure of a genome and depends on a coordinative work of the numerous mutators and anti-mutators genes, regulatory genetic elements responsible for the course of the main matrix processes $[23,24]$. There is a question who is a «managing director» of all this machinery? Whether it operates at higher levels of the organization above cell populations or maybe the regulation of mutagenesis is determined by the internal self-functioning of cell genome?

In a post-genomic era with the appearance of new opportunities for studying the principles of genomes organization and function it became obvious that the features of primary DNA structure, existence of standard epigenetic marking of genes by methylating, functional activity of a cell, fidelity of matrix processes and many other factors influence spontaneous mutagenesis [25]. Just illustrating one of the important points, «there is an opinion according to which violations in the standard of epigenetic marking of genes in stem and progenitor cells can be the reason of emergence of a cancer that is accompanied by DNA damages» [15].

We succeeded to get some data in favor of this hypothesis analysing the rearrangements of chromosomes while isolating stem cells from mammalian organism and cultivating them with adaption to new conditions in vitro [26-28]. The human and mouse cells were passed hundreds of generations in culture, and now they might be considered as spontaneously immortalized cell lines $[26,27]$. It should be noted that the cells grew up as a standard monolayer culture and were not treated by any mutagenic compound.

As it was shown earlier by other authors earlier, we also revealed two stages in the forming of established cells lines: the first stage is characterized by structural instability, and the second one by stabilization of the karyotype. The comparative cytogenetic analysis of human and mouse stem cells at different passages of cultiva- tion showed that the karyotype of the former was more stable $[28,29]$. However, many various chromosomal aberrations (translocations, deletions, insertions) and changes of chromosome numbers in populations of human cells have been revealed [30].

However, in both human and mouse cells, we found one general tendency: increasing level of $M G M T$ gene expression in the period of structural instability, and then gradual decreasing in its expression, during the stabilization stage. After long cultivation of the human cell line 4BL it was impossible to reveal either mRNA, or MGMT protein in its regular form $(24 \mathrm{kDa})$ although there was constantly present a protein with a larger molecular weight $(50 \mathrm{kDa})$ which was recognized by specific monoclonal antibodies [30-32]. A decrease in a level of the expression of MGMT might be caused by methylation of the corresponding promotor and/or body of this gene.

By the comparative genome hybridization method the deletion of the area of 10 chromosome where MGMT gene is localized, and even more, the complete loss of one from two chromosomes 10 was revealed in the part of cell population [29]. The total absence of repair enzyme MGMT caused extremely high sensitivity of the human cells $4 \mathrm{BL}$ to the action of alkylating agent nitrosoguanidine (unpublished results). In the absence of chemical treatment the human cells preserved the viability, capacity to proliferation and differentiation.

Thus, the literature and our own data testify that during the formation of cell lines in vitro the genetic variability with evolution of karyotype is a result of spontaneous mutagenesis, and this process is followed by repression of the DNA repair systems [33]. These data are one more argument in favor of the idea about accelerated evolution of eukaryotic genomes under stressful environmental conditions. They also indicate that similar reorganization of cell genome under the influence of stress factors might be realized in the cells in vivo.

The question is whether it is possible to regulate the mutation process externally by means of natural nucleotide sequences (oncoviruses, MGEs) or by the DNA-constructions created by genetic engineering or by separate proteins (hormones, growth factors, cytokines) in eukaryotic cell systems.

Mutagenesis induced by exogenous biological factors. In everyday life we constantly face chemical and biological mutagens; often they act as a complex. 


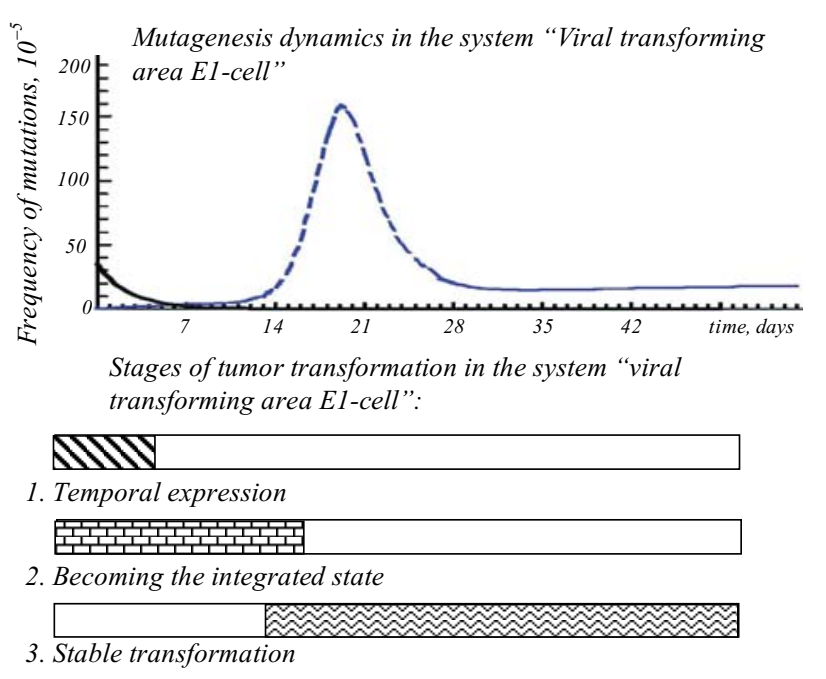

Fig. 1. Induction of mutations and reprogramming the mammalian cells to tumor transformation under the influence of transforming area E1 (early operons E1A+ E1B) of oncogenic adenovirus BAV-3

However, it is difficult to agree with the classification of mutagens where for the first time biological factors were included in the category of chemical mutagens, and nothing was said about specifics of their mutagenic action [2]. Such state of things served as one more argument to consider this question.

It is the International agency on research of cancerogenic risk in the World Health Organization (WHO), which concluded that food is a source of a complex mix of mutagens and carcinogens of different nature [34]. An application of genetically modified food and recombinant DNAs on the basis of virus vectors and human cells as pharmaceutical preparations for gene and cell therapy, poses a problem of genetic consequences of alien biological factors introduced into a human body [35-37].

To the biological factors, influencing mutational process towards both its increase and fall, belong viruses, nucleic acids, MGEs, various cellular metabolites, hormones, enzymes, vitamins, etc. [38]. As it has been already noted, MGEs and oncoviruses are especially distinguished as mutagenic factors which are capable not only of destabilizing but also of carrying out full reprogramming of the cell genome on the way to malignant transformation [8, 14-16].

The data obtained by researchers of several laboratories using oncoviruses of different groups, convincingly showed that an induction of gene mutations under the influence of these factors in somatic mammalian cells in vitro [39-44] and in vivo [45-47] is a uni- versal phenomenon. Essential differences in the mutagenic effects which were produced by exogenous viruses or DNAs in experiments with Drosophila melanogaster $[3,12,13,48]$ were found. As a rule, in mammalian cells the increasing of general mutagenesis was observed, i. e. mutations were revealed in all genes which researchers investigated. The types of mutations were others: mainly, breaks of chromosomes and replacement of bases that pointed to a possible role of DNA replication and reparation in the observed mutagenic effect. Insertions of the exogenous nucleotide sequences into the mutants by DNA-genome viruses, were not found at all $[4,6,7,44]$. In the case of retroviruses they did not exceed $4 \%[41,42]$, and in transgenic animals $8 \%$ [45-47].

A basic point of our further investigations on mapping mutagenic activity was the assumption that the transforming area of oncogenic adenovirus which stimulates cell DNA replication and causes malignant transformation, is mutagenesis inducer as well. In the article published in the J. Cell. Sci. in 1985, were presented our results which testified that oncogene or E1B operon of adenovirus, responsible not only for maintenance of malignant transformation but also for mutagenesis in somatic mammalian cells [49]. This work was admitted as the first attempt of mutagenesis regulation by means of a transforming gene [50].

We developed and approved a special methodical approach: using restriction fragments of adenoviral genome, regulatory genetic elements, TPA tumor promotor, nucleotide-threephosfates, by means of which it was possible to modulate mutagenic effects [7]. The TPA was tested in experiments with using carcinogens of different nature [51]. This approach allowed us to establish the effect of increasing mutations frequency with all early operons (E1A, E1B and E4) of bovine adenovirus type 3 (BAV3) and to show the dependence of mutagenic effect on the level of viral oncogenes expression $[49,51]$. The maximal mutagenic effect (10-20-fold excess of mutation frequency in relation to control), comparable to the action of chemical supermutagen nitrosoguanidine, was found with viral transforming E1 area (Fig. 1).

The system of early adenoviral operons allowed us to demonstrate how oncogenic virus «manages» the tumor transformation and mutagenesis in eukaryotic cell system. It is known that transforming E1 area (operons 


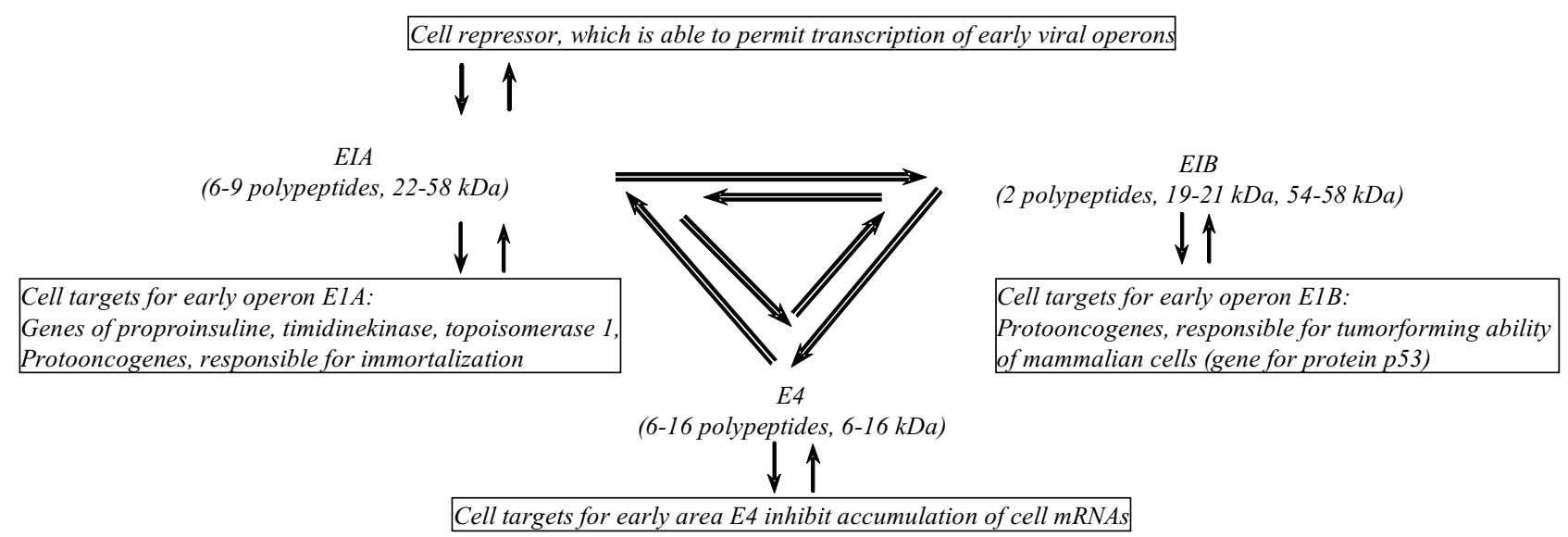

Fig. 2. Interactions of early operons (E1A, E1B, E4) of oncogenic adenovirus BAV-3 between themselves and with cellular genes during reprogramming the mammalian cells to tumor transformation

E1A, E1B) interacts with many cellular genes, stimulating the expression of cellular targets responsible for DNA replication and cells proliferation, but the early E4 area on the contrary suppresses accumulation of cellular mRNA and thus prevents the development of infectious process (Fig. 2). Similarly the E4 area acted in our system: it blocked the manifestation of induced mutagenesis at joint introduction with the transforming E1 area or E1B operon and thus prevented damage of cell DNA $[52,53]$. That is why the mutagenic effect of the total oncovirus was much less comparing with the mutagenic effect of its transforming E1 area only.

Our data on mutagen activity of the transforming viral genes were coordinated with the results received by other authors with fragments of genomes of different DNA-containing viruses: highly oncogenic human adenovirus type 12 [54-56] and herpes simple virus type $1[57,58]$. The mutagenic properties of SV40 T-antigen, encoded by early gene $A$, have been shown [59]. It was not excluded that mutagenesis, induced by oncogenes of cellular origin which were entered as a part of recombinant plasmids [60-62], was also connected with their proteins since no insertions of exogenous DNA were found in mutants [62].

The data on the ability of viral or cellular oncoproteins to induce gene mutations allowed us to pass from complicated model «exogenous DNA-cell» to more simplified model «exogenous protein-cell». We used a number of the proteins, capable of revealing mutagenic and cytotoxic activities and causing the programmed death: apoptosis. It has been shown that such different proteins as human hormone insulin and cytokine EMAP II and lectins of plant and animal origin induced gene mutations in somatic mammalian cells at early terms after their introduction [7, 63, 64]. Direct dependence of the induced mutagenic effect on the concentration of lectins in a wide range of doses was shown [63].

The investigated lectins of different origin at concentration of $0.2 \mu \mathrm{g} / \mathrm{ml}$ modulated mutagenesis, induced by chemical mutagen ni.trosoguanidine, towards its drop, acting in this case as antimutagens. It testifies that proteins and nitrosoguanidine are able to compete for the general cellular targets although they presumably af- fect different cell mechanisms. It is known that lectins reversibly interact with receptors of a superficial cel- lular membrane and influence various signal-regulato- ry ways. According to the literature and our own data, the studied carbon-containing proteins are capable to stimulate cell proliferation at small concentration, whi- le at higher concentration (2 $\mu \mathrm{g} / \mathrm{ml}$ and above) on the con- trary - to induce cytotoxic effect and apoptosis $[65,66]$.

The studied mutagenic effects were realized providing that the exogeneous factors actively interfere with the systems for maintenance of genetic stability via mechanisms of nucleic-protein recognition [67]. So, if exogenous nucleotide sequences were not expressed in the cell system due to the lack of special regulatory elements or considerable damage of matrix properties, as a result of alkylation, heating or UV-light, they did not show the genetic activity as well $[7,43,52,53,68]$. It is possible to make some conclusions about possible mecha- 
nisms of mutagenic action of exogenic biological factors. S. M. Gershenzon emphasized that, unlike physical and chemical mutagens, macromolecules cannot cause socalled adducts, in the structure of cell DNA $[3,12,13]$. It seems to be the most probable explanation that exogenous DNAs which keep matrix properties have regulatory and information impact on cell DNA via the systems for maintenance of genetic stability and involve the same mechanisms as at spontaneous mutagenesis but with participation of alien genetic materials $[69,70]$.

Regulatory influence of exogenous biological factors on matrix processes. Both exogenous transforming DNAs and individual proteins under special conditions were able to stimulate cell proliferation and induce gene mutations in eukaryotic cell systems. However, at the external similarity of a phenomenon they caused reprogramming cells diversely and, therefore, influenced different signal-regulatory ways and molecular mechanisms.

The assumptions concerning mechanisms of mutagenic action of DNA-genome viruses consist in: 1) stimulation of additional points of origin replication and correspondingly more DNA breaks [71]; 2) amplification of unstable sites of cell DNA (dynamic mutations) $[72,73]$; 3) reverse transcription and transposition of MGEs [9, 71-74]; 4) decreasing in accuracy of DNA biosynthesis [75].

Early adenoviral operons interact among themselves and activate many cellular targets responsible for the stimulation of cell DNA replication (Fig. 2). The early E1 area revealed the maximal mutagenic [7, 42, 43, $69,70]$ and transforming activity $[71,76]$. The function of proteins of E1A operon consists, mainly, in immortalization of primary mammalian cells, and the proteins encoded by E1B operon are necessary for both induction, and maintenance of transformed state [76]. The protein $58 \mathrm{kDa}$ encoded by an E1B operon, directly contacts protein $\mathrm{p} 53$ which plays a key role in regulation of a cellular cycle $[56,77]$. The role of products of $E 4$ early operon in transformation is not clear, but it is known that the protein, encoded by it, contacts protein $58 \mathrm{kDa}$ [78]. Thus, «managing» the viral operon via protein p53 is able to regulate cell switching on a way of reparation or apoptosis $[56,79]$.

Concerning investigated lectins there are data on their ability to induce apoptosis; and for some of them (lectins from bark and inflorescences of Sambucus nig$r a$ ) one-thread breaks in individual mammalian cells were directly detected by means of the DNA comet method [80]. In our recent work the induction of the corresponding apoptotic proteins under the influence of phytogemagglutinin and its isoforms has been shown (unpublished results). Besides, it is impossible to exclude that mutagenic activity of some lectins is realized through their specific enzymatic activity, such as $\mathrm{N}$ glycosidase which leads to formation of apurine gaps in the cellular DNA. There are data about the lectins of RIP group which are capable not only of causing apurine gaps but also of inhibiting an excision repair process $[81,82]$.

Inhibition of an excision reparation under the influence of oncoviruses was observed in all types of cell systems, especially at joint action with chemical mutagens, for example, nitrosoguanidine [33, 83]. We assumed that the presence in the cells of a large number of molecules of an exogenous DNA matrix of different origin can distract considerable part of correcting and repairing enzymes and thus promote formation of the induced mutations in cell DNA. As it has been already mentioned, the unique MGMT repair enzyme which corrects one of the most dangerous damage, $\mathrm{O}^{6}$-methylguanine, induced by nitrosoguanidine $[84,85]$ was studied in our research.

There was a considerable strengthening of mutagenic effect of nitrosoguanidine in the presence of virus particles, native or alkylated DNAs, which are good substrates for MGMT enzyme, in mammalian cells in vitro [68]. When the molecules of modified base $\mathrm{O}^{6}$-benzylguanine almost completely inhibited activity of MGMT, there was observed the maximal increasing frequency of mutations in hprt locus induced by nitrosoguanidine $[86,87]$.

The molecular analysis of the mutations, induced by nitrosoguanidine at the active and suppressed reparative activity, allowed detailed study on the features of MGMT enzyme activity. On the contrary to the enzymes of excision repair system, MGMT was equally effective in removing methyl groups from both transcribed and nontranscribed threads of DNA, and showed the increased accuracy in the correction of damages in GC-rich areas which have higher temperature of melting and save a double-stranded structure for a longer time [86-88]. 
As it is already specified, at joint action of lectins and nitrosoguanidine the decreasing mutagenic effect was observed. Lectins, unlike oncoviruses, stimulated apoptosis in non-permissive cell systems. Besides, it was shown that lectins and cytokine EMAP II strengthened the expression of proteins which were recognized by monoclonal anti-MGMT antibodies [30-32]. Thus, these kinds of proteins might be used for strengthening repair system which removes alkyl groups from cellular DNA. Investigations of various MGMT inhibitors and activators have special value for further optimization of chemotherapy by alkylating compounds $[90,91]$.

Regulatory influence of E1 transforming area of oncogenic adenovirus on replication and reparation cannot explain its complete mutagenic effect. In mammalian cells any exogenous transforming DNA including viral one, undergoes quite long evolution [71, 92-98]. Researchers distinguished the following stages of genetic transformation: 1) temporary expression; 2) creation of the integrated structure (characterized by formation of macromolecular complexes and structural instability); 3) stable transformation; 4) involution of alien nucleotide sequences when they are exposed to methylation and eliminated. Sometimes in transformed cells there were completely absent viral nucleotide sequences but changed cell phenotype remained [98].

When studying the dynamics of mutagenic action of E1 transforming area we found two liftings of mutation frequency: in early terms after transfection which corresponds to a stage of a temporary expression and in more remote terms corresponding to the period of structural instability (Fig. 1). The remote mutagenic effect was synchronized with the maximum of tumors induced by oncovirus [7, 52, 53, 69, 70].

Comparison of exogenous DNAs, introduced into the cells by different methods, with MGEs, opened by Mac-Klintok in 1956, seems to be reasonable. Hesin considered that practically any nucleotide sequence surrounded with DNA-repeats, might become a mobile genetic element [3]. Thus it is necessary to consider that the MGEs of various types can be introduced into the cellular system with exogenous DNAs while some MGEs might be activated in cell genome as a result of transfection or genomic stress [70,73].

We have shown the induction of gene mutations after the introduction of human Alu-repeat as a part of the recombinant plasmid into Chinese hamster cells in vitro $[7,68]$. The mutagen activity of Alu-repeat which does not code for protein products, but is an actively expressed genetic element, testifies to a possible role of RNA transcripts in mutagenic process with turning on the mechanism of reverse transcription and transposition $[9,71-73]$.

We undertook bioinformation search which revealed the existence of a large number of MGEs of various classes in human genome (including MGMT gene) [99, 100]. MGEs transpositions, apparently, play an essential role in processes of normal development, and differentiation of stem cells, as well as in malignant transformation. But a question was posed, why as a response to introduction of various natural and synthetic polynucleotides into the sexual cells of drosophila, some specific mutations appeared in certain loci $[12,13]$. It was postulated that probably different transpositions of various MGEs in the corresponding sensitive sites of cellular DNA were induced. In a genome of higher eukaryotes where coding sequences are only «islands in the ocean» (3-5\% of a genome), MGEs integration most often happens in nucleotide sequences of excess DNA $[9,17,18,70,101,102]$.

In the research of Gazaryan et al. on transgenic mice with a recombinant plasmid $p B R 322$ containing Raus sarcoma provirus, the integration of plasmid nucleotide sequence in a mouse genome $[45,46]$ was shown in several cases. However, direct link between an insertion and a mutation came to light not always. Besides, loss of viral nucleotide sequences did not lead to a change in the mutant phenotype. The authors also came to a conclusion that the transfection resulted in the induction of transpositions of cell MGEs which caused locus specific mutations.

When studying biological mutagenesis in somatic mammalian cells in vitro the locus specificity was not revealed. However, the existence of areas on chromosomes, in places of concentration of the Alu-repetitions sensitive to action of different mutagens $[9,72,73]$ was established. The analysis of the data specified that Alu-elements can act as «hot spots» of recombinational and mutational events, and also mediators of homological and nonhomological recombinations. From this point of view hprt gene chosen by us for investigations which incorporates 49 copies of the Alu-element, pla- 


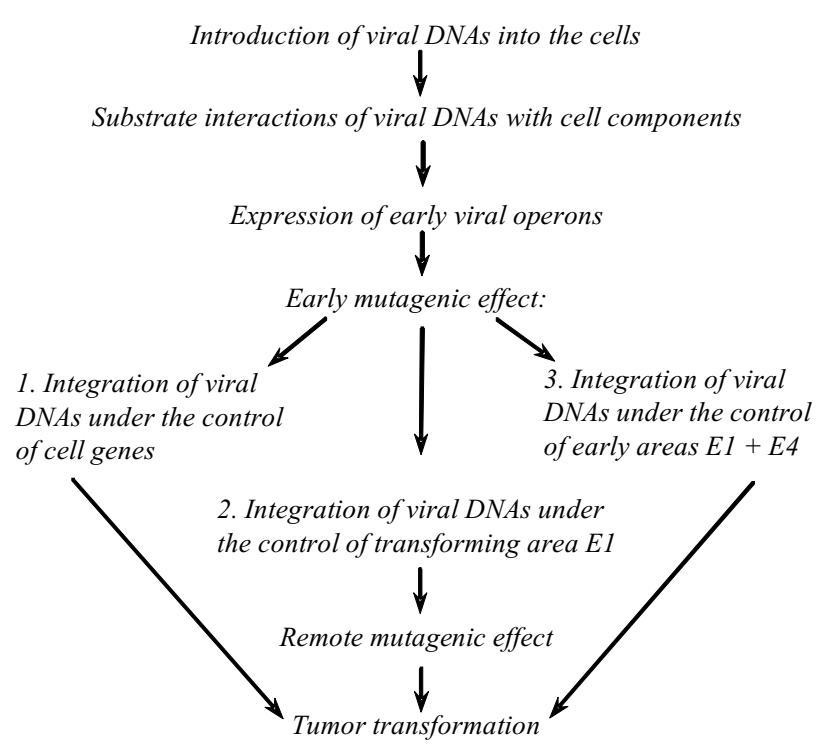

Fig. 3. Sequence of the events in the system «adenovirus-cell» during reprogramming the mammalian cells to tumor transformation

ced in sense- and antisense directions, is a perspective model locus for mutational researches [103].

Mathematical remodeling of induced mutagenesis was carried out to allocate the factors determining mutagenic process in the system «adenovirus-cell» $[104$, 105]. Summarizing the data, we allocate three major factors of destabilization in the nonpermissive cell system «oncovirus-cell» (Fig. 1-3). The primary factor of destabilization is the expression of the early regulatory viral genes responsible for stimulation of DNA replication and malignant transformation. The secondary factor of destabilization is reprogramming cellular genome (change in the activity and mutations of cellular genes and regulatory elements, transpositions of MGEs) under the influence of the expression of early viral genes and their integration with cellular DNA. An additional factor which increases probability of mutations is a capability of exogenous genetical matrix to interact with cellular DNA-connecting repair enzymes. The final resultant effect of mutagenesis and malignant transformation is defined by interaction of viral and cellular genes.

Mutagenesis and reprogramming the cells. In the course of malignant transformation under the influence of oncoviruses, the destabilization of a cell genome is taking place [4-7, 69]. However, in most cases the mutations themselves do not define the end result, and only provide a genetic variety for selection at the cell population level. Presumably, the failures of genetic pro- gramming or realization of incorrect program of gene expression under virus influence play main role.

It is possible to assume that a sharp change in the gene expression program is accompanied by mutational and recombinational variability as it occurs, for example, at the formation of antibody producing cells [22]. For example, the induction of genetic damages might be observed during reprogramming the cells which happens at the differentiation of stem cells into specialized tissues under the influence of the corresponding regulatory signals, growth factors, cytokines, etc. The study on signal-regulatory ways in stem cells opens a new page in research of mutagenesis regulation and in understanding its true role in the development and differentiation [106]. It has a special value when investigations deal with populations of stem and progenitor cells which are intended to be used for cell therapy of human diseases $[107,108]$ or for creation of «knock-out» animals when remodeling human diseases [109]. Therefore the study on mutagenesis in populations of stem cells in vitro and in vivo is promoted.

In differentiated cell populations there are conditions for emergence of mistakes in cellular DNA. There are the errors of epigenetic changes in the standard methylation which are followed by DNA damages [15] and MGEs tranpositions [9, 17, 18, 72, 73, 98]. This supposition is supported by the data that stem cells are more resistant to external mutagens and mutate with lower frequency in comparison with specialized cells [110].

Of course, a rejection of the cells, not corresponding to a new program, by apoptosis takes place; however, some damages are realized into mutations which might serve as sources of different diseases. Various chromosomal mutations arising at differentiation of germinal cell lines and realizing into diseases of reproductive system are considered in details [111].

Mutagenesis and reprogramming are the necessary components or mechanisms of eukaryotic cell systems. Thus mutagenesis has to be accepted as a reality and should be studied for realizing a possibility to control it [112]. We tried to apply a system biology approachs of minimization, simplification and mathematical remodeling to eukaryotic cell systems in vitro for better understanding how to operate mutagenesis with a help of biological factors, and then to use this knowledge for bet- 
ter understanding a human organism with all its specific features.

Considering the spontaneous and induced mutation process, one can understand that it is necessary to use pharmaceuticals reasonably because some of them are mutagenic, and their irrational application leads to emergence of new forms of pathogens, microorganisms resistant to any medical preparation [113]. The application of antimutagens cannot be a panacea, because their action depends on many factors: concentrations and activities, penetration and metabolic changing under the influence of internal conditions, interaction with an individual organism. Nobel laureate James Watson has made a sensational announcement that too intensive application of antioxidants preparations which serve as antimutagens might be harmful for people increasing the risk of cancer and diabetes development.

Certainly, rather simple cellular systems (somatic mammalian cells in vitro) are created and supported by the researcher, as the laboratory lines of animals, for example knock-out mice [109]. Manipulating experimental models the researcher begins to understand better the own organism as a device. It is possible to learn, for example, with a help of virus how to operate with mutagenesis and reprogramming cellular genome. The oncovirus is acting as a «managing director» in the cell during long time, but a cell often gets rid of it or silences it [71, 46-48, 92-98]. Still, in any case the recovery of a cell comes when virus mission is completed, information is transferred, and the cell system is changed or reprogrammed. Operating with the model systems the researcher realizes that the human genome is also a set of the computer programs which are a subject for testing, optimization, and if necessary - reorganization.

At the same time the managing director is only dealing with what is given to him but the all program should be known only at higher levels of the organization. It looks like the researcher who has created a cellular model for studying mutagenesis, acts at a higher level regarding this model. The man can become the managing director of himself as well: an individual after all has the right to dispose the own organism (i.e. cell populations, of which he, as a matter of fact, consists). At the same time everyone should remember that he is only a small part of the nature which is, a matter of fact, reprogramming our development. Otherwise, we evolve to- gether with viruses and all noosphere would have stopped existence long time ago at quickly changing conditions of the modern world.

However, it seems that our consciousness does not always keep up in accordance with real life and certainly influence on health and morbidity [114]. So, maybe, first of all, it is necessary to raise the level of our own self-consciousness, at least, to become the managing director of the own organism.

\section{Л. Л. Лукаш}

Регуляція мутагенезу екзогенними біологічними чинниками в евкаріотних клітинних системах

Резюме

Проаналізовано уявлення щзодо природи мутаџій $і$ спонтанного мутаційного процесу, а також мутагенезу, індукованого екзогенними онковірусами, ДНК і білками-мітогенами. Екзогенні біологічні чинники індукують пошкодження ДНК регуляторно-інформаційним иляхом, діючи на системи підтримки генетичної стабільності. Молекулярні механізми мутаџій такі самі, як $і$ за спонтанного мутагенезу, але реалізуються за участі чужорідного генетичного матеріалу. Серед біогенних мутагенів виокремлюють онковіруси і мобільні генетичні елементи (МГЕ) як найсильнімі дестабілізувальні фактори, щзо контролюють процес злоякісної трансформації соматичних клітин ссавців. Генетичне перепрограмування або зміна програм генної експресії при диференціюванні стовбурових клітин і клітин-попередників під впливом ростових факторів и ичитокінів, ймовірно, також супроводжується мутаціями й рекомбінаціями.

Ключові слова: мутагенез, мутація, клітини евкаріотів, онковіруси, МГЕ, білок-мітоген.

\section{Л. Л. Лукаш}

Регуляция мутагенеза экзогенными биологическими факторами в эукариотных клеточных системах

\section{Резюме}

Проанализированы представления о мутациях и природе спонтанного мутационного процесса, а также о мутагенезе, индуцированном экзогенными онковирусами, ДНК и белками-митогенами. Экзогенные биологические факторы индуцируют повреждения ДНК регуляторно-информационным путем, оказывая влияние на системы поддержания генетической стабильности. Молекулярные механизмы мутаций такие же, как и при спонтанном мутагенезе, но реализуются при участии чужеродного генетического материала. Среди биогенных мутагенов выделяют онковирусы и мобильные генетические элементы (МГЭ) как наиболее сильные дестабилизирующие факторы, контролирующие процесс злокачественной трансформации соматических клеток млекопитающих. Генетическое перепрограммирование или смена программ генной экспрессии при дифференщировке стволовых клеток и клеток-предшественников под влиянием ростовых факторов и цитокинов, по-видимому, также сопровождается мутациями и рекомбинациями.

Ключевые слова: мутагенез, мутаиия, клетки эукариотов, онковирусы, МГЭ, белок-митоген. 


\section{REFERENCES}

1. Drake J. W. Looking backward on a century of mutation research // Environ. Mol. Mutagen.-1994.-23, Suppl. 24.-P. 11-14.

2. Ivanov V. I., Baryshnikov N. V., Bileva Dj. C., Dadali E. L., Konstantinova L. M., Kuznetsova O. V., Polyakov A. V. Genetics.M: IKTs «AKADEMKNIGA», 2006.-638 p.

3. Gershenzon S. M., Aleksandrov Yu. A. Malyuta S. S. Mutagenic action of DNA and viruses at drosophila.-Kiev: Naukova dumka, 1975.-160 p.

4. Shapiro N. I., Marshak M. I., Varshaver N. B. Mutagenic effects of DNA-containing oncogenic viruses and malignant transformation of mammalian cells // Cancer Genet. Cytogenet.-1984.13, N 2.-P. -167-179.

5. Buzhiyevskaya T. I. Virus-induced mutagenesis.-Kiev: Naukova dumka,1984.-134 p.

6. Lukash L. L., Buzhievskaya T. I. Role of early viral genes in mutagenesis // Biotechnology. Current progress.-Lancaster: Technomic Publ. Co. Inc., 1991.-P. 119-132.

7. Lukash L. L. Destabilization of a cellular genome under the influence of an expression of early regulatory genes of oncoviruses // Cytol. Genet.-2002.-36, N 2.-P. 66-68.

8. Hesin R. B. The variability of a genome.-M: Nauka, 1984.-472 p.

9. Akif'ev A. P., Khudolii G. A. Mutagenesis and genetic homeostasis in higher organisms // Vestn. Ross. Akad. Med. Nauk.1993.-N 1.-P. 3-9.

10. Zhimulev I. F. General and molecular genetics.-Novosibirsk: Sib. Univ. publ. house, 2003.-480 p.

11. Houle D., Kondrashov A. Mutation // Evolutionary Genetics.Oxford: Univ. press, 2006.-P. 32-48.

12. Gershenson S. M., Alexandrov Yu. N. Molecular mechanisms of mutagenicity of DNA and other natural and synthetic polynucleotides.-Kiev: Naukova dumka, 1997.-262 p.

13. Gershenzon S. M., Aleksandrov Yu. M., Malyuta S. S., Buzhievskaya T. I., Karpova I. S., Larchenko K. A. Mutagenic action of nucleic acids and viruses.-Kyiv: Znannya, 1999.-29 p.

14. Grishanin A. K., Shekhovtsov A. K., Boikova T. V., Akif'ev A. P., Zhimulev I. F. Chromatin diminution at the border of the XX and XXI centuries // Tsitologiia.-2006.-48, N 5.-P. 379-397.

15. Feinberg A. P., Ohlsson R., Henikoff S. The epigenetic progenitor origin of human cancer // Nat. Rev. Genet.-2006.-7, N 1.P. 21-33.

16. Kolotova T. Yu., Volyansky A. Yu., Kuchma I. Yu. et al. Instability of a genome and epigenetic inheritance at eukaryotes.-Kharkiv: Oko, 2007.-287 p.

17. Rubtsov N. B., Borodin P. M. Evolution of chromosomes: from A to B and back // Nature Magazine.-2002.-N 3.-P. 59-66.

18. Akifyev A. P. Excess DNA - a genetic quadrature of a circle? // Nature Magazine.-2004.-N 10.-P. 3-11.

19. Shapiro N. I. Varshaver N. B. Rate of the spontaneous mutation process in mammalian somatic cells and several related questions // Genetika.-1976.-12, N 7.-P.-132-149.

20. Drake J. W. The distribution of rates of spontaneous mutations over viruses, prokaryotes and eukaryotes // Ann. NY Acad. Sci.-1999.-870.-P. 100-107.

21. Zhestyannikov V. D. DNA reparation and its biological value.Leningrad: Nauka, 1979.-286 p.

22. Kholodna L. S. Imunology.-Kyiv: Vishcha shkola, 2007.-271 p.

23. Alekperov U. K. Antimutagenesis.-M: Nauka, 1984.-100 p.

24. Lukash L. L. Mutagenesis and antimutagenesis are contrary direciod processes determining the level of genetic variability and stability // Biopolym. Cell.-1998.-14, N 6.-P.-500-511.
25. Cherepenko E. I., Hovorun D. M. The updated picture of spontaneous mutagenesis could involve DNA bases tautomerism // Biopolym. Cell.-2007.-23, N 3.-P.-155-166.

26. Lukash L. L., Iatsishina A. P., Pidpala O. V., Vagina I. M, Kochubey T. $P$. Obtaining new lines of mouse stem cells and studying microenvironment influence on their karyotipic variability in vitro // Physiology and Biochemistry of Cultural Plants.2006.-38, N 2.-P. 144-152.

27. Lukash L. L., Iatsishina A. P., Kushniruk V. O., Pidpala O. V. Reprogramming of human somatic adult cells in vitro // Factors of experimental evolution of organisms.-Kiev: Logos, 2011.Vol. 11.-P. 493-498.

28. Iatsyshyna A. P., Pidpala O. V., Kochubey T. P., Lukash L. L. Cytogenetical analysis of spontaneously immortalized mouse cell line // Biopolym. Cell.-2006.-22, N 4.-P. 299-306.

29. Akopyan G. R., Guleyuk N. L. Kushniruk V. O., Mikitenko D. M., Iatsishina A. P., Lukash L. L. Comparative analysis of karyotype of a new line of human cells in conditions of long time cultivation. 1. Ploidy of chromosomal set // Tsitologiia i genetika.2013.-47, N 5.-P. 55-96.

30. Iatsyshyna A. P., Lylo V. V., Pidpala O. V., Ruban T. P., Vagina I. $M$, Lukash L. L. The expression of $\mathrm{O}^{6}$-methylguanine-DNA methyltransferase in the spontaneously immortalized mouse cell line G1 and its sublines G1-OA and G1-T // Biopolym. Cell.2007.-23, N 3.-P. 250-254.

31. Lylo V. V., Macewicz L. L., Kotsarenko E. V. et al. Activation of gene expression of the $\mathrm{O}^{6}$-methylguanine-DNA-transferase repair enzyme upon the influence of EMAP II cytokine in human cells in vitro // Cytol. Genet.-2011.-45, N 6.-P. 373-378.

32. Kotsarenko E. V., Lylo V. V., Macewicz L. L. et al. Change of an expression of $M G M T$ gene for repair enzyme under the action of exogenous cytokies in human cells in vitro // Tsitologiia $\mathrm{i}$ genetika.-2013.-47, N 4.-P. 9-18.

33. Zasukhina G. D. Reparation mechanisms of cells and environment problems.-M: Nauka, 1979.-184 p.

34. Genomics and World Health.-Geneva: WHO, 2002.-241 p.

35. Glasko V. I. Geneticaly modified organisms: from bacteria to the person.-Kiev: Ministery of Science and Education of Ukraine, 2002.-210 p.

36. Kordyum V. A., Frolkis V. V., Lukash L. L. et al. Gene therapy of mass pathologies // Biopolym. Cell.-1993.-9, N 4.-P. 63-104.

37. Rumyantsev A. G. Maschan A. A. Transplantation of haemopoietic stem cells at children.-M: MIA, 2003.-910 p.

38. Lukash L. L. Biological mutagens: their influence on stability of eukaryotic cell systems // Bull. Ukrainian Soc. Genetisists and Selectionists.-2003.-N 1.-P. 62-81.

39. Lukash L. L., Buzhievskaya T. I., Varshaver N. B., Shapiro N. I. Oncogenic adenovirus as mutagen for chinese hamster cells in vitro // Somatic. Cell. Genet.-1981.-7, N 2.-P. 133-146.

40. Marengo C., Mbikay M., Weber I., Thirion J. P. Adenovirus-induced mutations at the hypoxanthine phosphoribosyltransferase locus of Chinese hamster cells // J. Virol.-1981.-38, N 1.P. 184-190.

41. Jenkins N. A., Copeland N. G., Taylor B. A., Lee B. K. Dilute (d) coat colour mutation of DBA/2J mice is associated with the site of integration of an ecotropic MuLV genome // Nature.-1981.293, N 5831.-P. 370-374.

42. Varmus H. E., Quintrell N., Ortiz S. Retroviruses as mutagens: insertion and excision of a nontransforming provirus alter expression of a resident transforming provirus // Cell.-1981.-25, N 1.-P. 23-36.

43. Schlehofer J. R., Hausen H. Z. Induction of mutations within the host genome by partially inactivated herpes simplex virus type 1 // Virology.-1982.-122, N 3.-P. 471-475. 
44. Pilon L., Langelier L., Royal A. Herpes simplex virus type 2 mutagenesis: characterization of mutants induced at the hprt locus of nonpermissive XC cells // Mol. Cell. Biol.-1986.-6, N 8.P. 2977-2983.

45. Gazaryan K. G. Microinjections of genes in zygotes and embryos: integration into a genome and genetic effects // Uspekhi Sovremennoy Genetiki.-M.: Nauka, 1985.-Vol. 13.-P. 75-88.

46. Tarantul V. Z., Kuznetsova E. D. Gazaryan K. G. Characteristic of segments of transgenic animal genomes, adjacent to integrated sequences of foreign DNA // Mol. Biol (Mosk).-1989.-23, N 4.-P. 1036-1040.

47. Gordon J. W. A foreign dihydrofolate reductase gene in transgenic mice acts as dominant mutation // Mol. Cell. Biol.1986.-6, N 6.-P. 2158-2167.

48. Gabitova L. B., Nabirochkin S. D., Begetova T. V., Gazarian K. $G$. Induction of unstable mutations in Drosophila melanogaster by microinjections of oncogenic virus DNA into the embryo polar plasma. Prolonged genetic instability of mutations at the lobe locus // Genetika.-1991.-27, N 4.-P. 617-624.

49. Lukash L. L., Varshaver N. B., Buzhiyevskaya T. I., Shapiro N. I. The oncogene of BAV-3 as a mutagen // J. Cell. Sci.-1985.78.-P. 97-103.

50. Sassone-Corsi P. Mutagenic activity of transforming genes // Trends Genetics.-1986.-2.-P. 6.

51. Manuilova E. S., Lukash L. L., Shapiro N. I. The action of the tumour promoter, TPA, on mutagenesis induced by different agents (UV light, chemical and viral mutagenesis) // Mutat. Res.-1987.-179, N 2.-P. 231-236.

52. Lukash L. L. Kovalenko O. A., Pidpala O. V. Influence of DNA fragments of adenovirus, containing early regulatory genes, on mutation process in mammalian cells in vitro // Factors of experimental evolution of organisms.-Kiev: Agrarna nauka, 2003.-P. 85-90.

53. Lukash L. L. Kovalenko O. A. Mapping of transforming and mutagen activity of adenoviruses // Bull. Ukrainian Soc. Genetisists and Selectionists.-2004.-N 1.-P. 104-121.

54. Durnam D. M., Smith P. P., Menninger J. C., McDougall J. K. The E1 region of human adenovirus type 12 determines the sites of virally induced chromosomal damage // Cancer Cells 4: DNA tumor viruses / Eds M. Botchan et al.-New York: Cold Spring Harbor Lab. Press, 1986.-P. 349-354.

55. Schramayr S., Caporossi D., Mak I., Jelinek T., Bacchetti S. Chromosomal damage induced by human adenovirus type 12 requires expression of the E1B 55-kilodalton viral protein // J. Virol.-1990.-64, N 5.-P. 2090-2095.

56. Zhao L. Y., Colosimo A. L., Liu Y., Wan Y., Liao D. Adenovirus E1B 55-kilodalton oncoprotein binds to Daxx and eliminates enhancement of p53-dependent transcription by Daxx // J. Virol.-2003.-77, N 21.-P. 11809-11821.

57. Shillitoe E. J., Zhang S., Wang G., Hwang C. B. Functions and proteins of herpes simplex virus type-1 that are involved in raising the mutation frequence of infected cells // Virus Res.1993.-27, N 3.-P. 239-251.

58. Das C. M., Zhang S., Shillitoe E. J. Expression of the mutagenic peptide of herpes simplex virus type 1 in virus infected cells // Virus Res.-1994.-34, N 2.-P. 97-114.

59. Drize O. B., Sokova O. I., Nikashina E. B., Shliankevich M. A., Shapot $V$. S. Possible role of the T antigen in inducing chromosome aberrations in SV40 virus-transformed cells // Tsitologiya.-1985.-27, N 1.-P. 76-82.

60. Baron H. M., Bobrisheva I. V., Varshaver N. B. The activated human c-Ha-ras-1 oncogene as a mutagen // Cancer Genet. Cytogenet.-1992.-62, N 1.-P. 15-20.
61. Bobrisheva I. V. Baron E. M. Varshaver N. B. The plasmid of pSVc-myc-1 induces gene mutations and chromosomal aberrations in cultivated Chinese hamster cells // Cytol. Genet.-1993.27, N 4.-P. 51-47.

62. Bobrysheva I. V. Varshaver N. B. Characteristics of mutants induced by the $c$-Ha-ras 1 oncogene and the nature of the oncogene's mutagenic action // Genetika.-1995.--31, N 12.-P. 1598 1604.

63. Kovalenko O. O., Kostetskaia K. V., Lukash L. L. The influence of lectins of different origin on mutagenic process of mammalian somatic cells in vitro // Biopolym. Cell.-2006.-22, N 1.-P. 33-37.

64. Kovalenko O. O., Lukash L.L., Lukash S. I. Induction of gene mutations by lectins of different origin and cytokine EMAP II in somatic mammalian cells in vitro // Biopolym. Cell.-2007.-23, N 5.-P. 410-415.

65. Lukash L. L. Karpova I. S. Miroshnichenko O. S., Tikhonova T. N., Lylo V. V., Man'ko V. G., Sukhorada E. M., Golynskaia E. $L$. The effect of the lectin from Sambucus nigra inflorescences on spontaneous and alkylating agent-induced mutagenesis in mammalian somatic cells // Cytol. Genet.-1997.-31, N 5.P. 47-52.

66. Kovalenko O. O., Lukash L. L. Antimutagenic effect of lectin and N-methyl-N'-nitro-N-nitrosoguanidine on induced mutagenesis in mammalian cells in vitro // Cytol. Genet.-2007.-41, N 6.-P. 381-384.

67. Travers A. DNA-protein interactions.-Amsterdam: Springer, 1993. $-180 \mathrm{p}$.

68. Lukash L. L. Podolskaya S. V., Sukhorada H. M., Kostetskaya K. V., Kostetsky I. E., Varzanova I. S., Patskovsky Yu. V., Vavilina $I$. $V$., Deys $S$. V.The Influence of alkylating agent MNNG on mutagenic effect of exogeneous recombinant DNA // Biopolym. Cell.-1995.-11, N 1.-P. 87-91.

69. Lukash L. L. The regulation of a variability of somatic mammalian cell genome under the influence of exogeneous biological factors // Biopolym. Cell.-2004.-20, N 1-2.-P. 93-105.

70. Lukash L. L. Mutagenesis induced by integration processes and evolution of nuclear genome // Biopolym.Cell.-2007.-23, N 3.P. $172-182$.

71. Ageenko A. I. Oncogenes and carcinogenesis.-M.: Medicina, 1986. $-256 \mathrm{p}$.

72. Shakhmuradov I. A., Kapitonov V. V., Kolchanov N. A., Omel'ianchuk L. V. Evolution of Alu repeats: dynamics of distribution in genome // Genetika.-1989.-25, N 9.-P. 1682-1689.

73. Lukash L. L. Shvachko L. P., Kostetskaya K. V. Mobile genetic elements in mutagenic process, recombination and malignization of human cells // Biopolym. Cell.-1996.-12, N 2.-P. 7-19.

74. Hoffmann J. S., Pillaire M. J., Garcia-Estefania D., Lapalu S., Villani $G$. In vitro bypass replication of the cisplatin-d $(\mathrm{GpG})$ lesion by calf thymus DNA polymerase beta and human immunodeficiency virus type 1 reverse transcriptase is highly mutagenic // J. Biol. Chem.-1996.-271, N 26.-P. 15386-15392.

75. Krutyakov V. M. Accuracy of DNA biosynthesis: proof-reading role of independent 3-5-endonucleases of mammals // Uspekhi sovremennoi biologii.-1997.-117, N 6.-P. 660-667.

76. Levin A. J. The adenovirus early proteins // Curr. Top. Microbiol. and Immunol.-1984.-110.-P. 143-167.

77. Huh J. J., Wolf J. K., Fightmaster D. L., Lotan R., Follen M. Transduction of adenovirus-mediated wild-type $\mathrm{p} 53$ after radiotherapy in human cervical cancer cells // Gynecol. Oncol.2003.-89, N 2.-P. 243-250.

78. Dyachenko N. S., Nas I., Berenchi et al. Adenovirus, cell, organism.-Kiev: Naukova dumka, 1988.-232 p. 
79. Filchenkov A.A. Stoika R. S. Apoptosis (physiological death of a cell).-Kyiv: MP «VITUS», 1995.-24 p.

80. Macewicz L., Suchorada O. M., Lukash L. L. Influence of Sambucus nigra bark lectin on cell DNA under different in vitro conditions // Cell Biol. Int.-2005.-29, N 1.-P. 29-32.

81. Grooteclaes M., Deveraux Q., Hildebrand J., Zhang Q., Goodman R. H., Frisch S. M. C-terminal-binding protein corepresses epithelial and proapoptotic gene expression programs // Proc. Natl Acad. Sci.-2003.-100, N 8.-P. 4568-4573.

82. Matassa A. A., Kalkofen R. L., Carpenter L., Biden T. J., Reyland M. E. Inhibition of PKCalpha induces a PKCdelta-dependent apoptotic program in salivary epithelial cells // Cell Death Differ.2003.-10, N 3.-P. 269-277.

83. Sinel'shchikova T. A., Chekova V. V., Zasukhina G. D. Mechanisms of impairment of DNA repair in human cells. Interferons stimulated DNA repair in xeroderma pigmentosum cells // Genetika.-1989.-25, N 9.-P. 1658-1663.

84. Pegg A. E., Dolan M. E., Moschel R. C. Structure, function, and inhibion of $\mathrm{O}^{6}$-alkylguanine-DNA-alkyltransferase // Prog. Nucleic Acid Res. Mol. Biol.-1995.-51.-P. 167-223.

85. Pegg A. E. Repair of $\mathrm{O}^{6}$-alkylguanine by alkyltransferases // Mutat. Res.-2000.-462, N 2-3.-P. 83-100.

86. Lukash L. L., Boldt J., Pegg A. E., Dolan M. E., Maher V. M., McCormick $J$. J. Effect of $\mathrm{O}^{6}$-alkylguanine-DNA-alkyltransferase on the frequency and spectrum of mutations induced by $\mathrm{N}$-methyl-N'-nitro-N-nitrosoguanidine in the HPRT gene of diploid human fibroblasts // Mutat. Res.-1991.-250, N 1-2.P. 397-409.

87. Lukash L. L., Lylo V. V., Man'ko V. G., Terent'ev A. G. The increasing mutagenic effect of nitrosoguanidine under the influence of modified bases during inhibition of repair AGT enzyme in mammalian somatic cells in vitro // Cytol. Genet.-2002.-36, N 3.-P. 38-41.

88. McGregor W. G., Chen R. H., Lukash L. L., Maher V. M., McCormick J. J. Cell-cycle-dependent strand bias for UV-induced mutations in the transcribed strand of excision repair-proficient human fibroblasts but not in repair-deficient cells // Mol. Cell Biol.-1991.-11, N 4.-P. 1927-1934.

89. Lylo V. V., Piven' O. A., Serebriakova K. V., Matsevich L. L., Lukash $L . L$. The influence of lectins on some repair processes in mammalian cells in vitro // Ukr. Biokhim. Zh.-2008.-80, N 6.P. 60-65.

90. Christmann M., Verbeek B., Roos W. P., Kaina B. O ${ }^{6}$-methylguanine-DNA methyltransferase (MGMT) in normal tissues and tumors: enzyme activity, promoter methylation and immunohistochemistry // Biochim. Biophys. Acta.-2011.-1816, N 2.P. 179-190.

91. Iatsyshyna A. P. Current approaches to improve the anticancer chemotherapy with alkylating agents: state of the problem in world and Ukraine // Biopolym. Cell.-2012.-28, N 2.-P. 83-92.

92. Popov L. S., Gorbunova L. V., Varshaver N. B., Shapiro N. I. Integration of SV40 DNA into cell genome and viral mutgenesis // Genetika.-1986.-22, N 9.-P. 2213-2219.

93 Stabel S., Doerfler W., Friis R. R. Integration sites of adenovirus type 12 DNA in transformed hamster cells and hamster tumor cells // J. Virol.-1980.-36, N 1.-P. 22-40.

94. Doerfler $W$. Uptake, fixation and expression of foreign DNA in mammalian cells: the organization of integrated adenovirus DNA sequences // Curr. Top. Microbiol. Immunol.-1982.101.-P. 128-188.

95. Kuhlmann I., Achten S., Rudolph R., Doerfler W. Tumor induction by human adenovirus type 12 in hamsters: loss of the viral genome from adenovirus type 12-induced tumor cells is compatible with tumor formation // EMBO J.-1982.-1, N 1.-P. 79-86.
96. Gahlman R., Doerfler $W$. Integration of viral DNA into the genome of the adenovirus type 2-transformed hamster cell line HE5 without loss or alteration of cellular nucleotides // Nucleic Acids Res.-1983.-11, N 21.-P. 7347-7361.

97. Kuhlmann I., Doerfler $W$. Loss of viral genomes from hamster tumor cells and nonrandom alterations in patterns of methylation of integrated adenovirus type 12 DNA // J. Virol.-1983.47, N 3.-P. 631-636.

98. Schultz M., Doerfler W. Detection of cellular DNA at site of viral DNA insertion in the adenovirus type 12-induced mouse tumor CBA-12-1-T // Nucleic Acids Res.-1984.-12, N 12.- P. 49594976.

99. Pidpala O. V., Iatsishina A. P., Lukash L. L. Human mobile genetic elements: Structure, distribution and functional role // Cytol. Genet.-2008.-42, N 6.-P. 420-430.

100. Pidpala O. V., Iatsishina A. P., Lukash L. L. Potentional cis-elements ALUSP-repeat on the promotor of $M G M T$ gene // Factors of experimental evolution of organisms.-Kyiv: Logos, 2009.Vol. 7.-P. 43-47.

101. Ratner V. A., Zabanov S. A., Kolesnikova O. V., Vasilyeva L. A. Induction of the mobile genetic element Dm-412 transtositions in the Drosophila genome by heat shock treatment // Proc. Nat. Acad. Sci. USA.-1992.-89, N 12.-P. 5650-5654.

102. Deininger P. L., Moran I. V., Batzer M. A., Kazazian H. H., Jr. Mobile elements and mammalian genome evolution // Curr. Opin. Genet. Dev.-2003.-13, N 6.-P. 651-658.

103. Edwards A., Voss H., Rice P. et al. Automated DNA sequencing of the human HPRT locus // Genomics.-1990.-6, N 4.-P. 593-608.

104. Lukash S. I., Lukash L. L., Zadorozhnyi V. F. Mathematical model of mutagenesis dynamics under the action of adenovirus DNA fragment // Biopolym. Cell.-1996.-12, N 3.-P. 7-16.

105. Lukash S. I., Lukash L. L. The influence of heterogeneity of somatic mammalian cell system on mutagenesis manifestation induced by transforming genes of adenovirus // Biopolym. Cell.1996.-12, N 6.-P. 25-35.

106. Popov B. V. Introduction into the cell biology of stem cells.Saint-Petersburg: SpezLit, 2010.-319 p.

107. Lukash L. L. Cell therapy of heart pathologies // Biotechnology.2008.-1, N 1.-C. 40-45.

108. Shablyi V. A., Kuchma M. D., Onishchenko A. N., Lukash L. L., Lobintseva $G$. S. Cryoconservation of human placental tissue as source of hematopoietic progenitor cells and multipotent mesenchymal stromal cells // Cell Transplantology and Tissue Engineering.-2012.-7, N 1.-P. 54-62.

109. Piven O. O., Kostetskii I. E., Macewicz L. L., Kolomijec Y. M., Radice G. L., Lukash L. l. Requirement for N-cadherin-catenin complex in heart development // Exp. Biol. Med. (Maywood).2011.-236, N 6.-P. 816-822.

110. Cervantes R. B., Stringer J. R., Shao C., Tischfield J. A., Stambrook $P$. J. Embryonic stem cells and somatic cells differ in mutation frequency and type // Proc. Natl Acad. Sci. USA.-2002.99, N 6.-P. 3586-3590.

111. Denisenko S. V., Daryi A. S., Kononenko M., Zerova-Lyubimova T. E. Genetics of reproduction.-Kyiv: Ferz TA, 2008.-650 p.

112. Kordium V. A. Mutations: what are they? // Biopolym. Cell.2007.-23, N 3.-P. 215-242.

113. Cherepenko E. I. Molecular protection mechanisms of a cell and farmacotherapy.-Kiev: Naukova dumka, 2012.-261 c.

114. Breiden G. Matrix of consciousness.-Sofiya: Izd-vo Sofiya, 2008. -255 p. 